Results suggest that the greatest value in having Clinical Psychology onsite is in relation to the indirect clinical work that is provided. Respondents spoke about the importance of having Clinical Psychology present at MDTs as well as being able to approach the Clinical Psychologist for ad-hoc consultation. Themes also reflected perceived benefits in relation to the service's safety, responsiveness, equitability and patient-centeredness. These qualitative findings are complemented by quantitative data from routine audit.

Potential impact In highlighting the benefits of having access to an onsite Clinical Psychologist, as perceived by the healthcare professionals who interface with the service, this project can inform future service developments locally as well as offering support for the adoption of similar provisions elsewhere.
43 BRIEF ENGAGEMENT AND ACCEPTANCE COACHING IN COMMUNITY AND HOSPICE SETTINGS (THE BEACHES STUDY): FINDINGS FROM THE DEVELOPMENT AND PILOT-TESTING OF A PSYCHOLOGICAL INTERVENTION TO ENHANCE WELLBEING AT TRANSITION INTO PALLIATIVE CARE

1,2Brooke Swash, ${ }^{3}$ David Gillanders, ${ }^{4}$ Anne Finucane, ${ }^{5}$ Sue Millington, 'Sabrina Norwood ${ }^{4}$ Juliet Spiller, ${ }^{4}$ Jenny Strachan, ${ }^{1}$ Josh Kreft, ${ }^{1}$ Nick Hulbert-Williams. ${ }^{1}$ University of Chester, UK; ${ }^{2}$ University of Cambridge, UK; ${ }^{3}$ University of Edinburgh, UK; ${ }^{4}$ Marie Curie UK; ${ }^{5} \mathrm{PPI}$ representative

\subsection{6/spcare-2019-mariecuriepalliativecare.43}

Diagnosis of terminal illness and subsequent transition into palliative care can cause fear and uncertainty, resulting in distress and decreased quality of life (Murray et al, 2007).

\begin{tabular}{|c|c|c|}
\hline \multicolumn{3}{|c|}{ January 2018: Cycle 1 Data Collection } \\
\hline Time Frame & Intervention & Outcome \\
\hline $\begin{array}{l}\text { February } \\
2018\end{array}$ & $\begin{array}{l}\text { Amendment of the electronic process so it is now compulsory } \\
\text { to complete the explanatory electronic DNACPR form when } \\
\text { submitting an e-toolbar DNACPR order for a patient }\end{array}$ & $\begin{array}{l}\text { It is now not possible to complete an e- } \\
\text { DNACPR toolbar decision without a full } \\
\text { electronic explanatory DNACPR form }\end{array}$ \\
\hline $\begin{array}{l}\text { February } \\
2018\end{array}$ & $\begin{array}{l}\text { Distribution of patient and family 'Advanced Care Planning' } \\
\text { information booklet across Gerontology wards }\end{array}$ & $\begin{array}{l}\text { Resources for patients and relatives } \\
\text { available in all } 3 \text { wards and in all } 3 \text { doctors } \\
\text { offices so staff aware/can distribute } \\
\text { appropriately }\end{array}$ \\
\hline March 2018 & $\begin{array}{l}\text { Presentation at the Deteriorating Patient Group - end of life } \\
\text { steering group }\end{array}$ & $\begin{array}{l}\text { Promoted discussion of initial findings with } \\
\text { senior management team and the creation } \\
\text { of a series of action points }\end{array}$ \\
\hline March 2018 & $\begin{array}{l}\text { Worked with a team across the Trust working on the } \\
\text { standardisation of handover for nursing staff across all wards }\end{array}$ & $\begin{array}{l}\text { Incorporation of resuscitation status to be } \\
\text { included in all handovers twice a day }\end{array}$ \\
\hline April 2018 & Presented findings at the Trust's Grand Round & $\begin{array}{l}\text { Educated and promoted discussion across } \\
\text { the Trust } \\
\text { Audit was to be rolled out across Trust } \\
\text { using same audit tool } \\
\text { Recruitment of a larger team to carry out } \\
\text { audit in other divisions }\end{array}$ \\
\hline May 2018 & $\begin{array}{l}\text { Presented findings locally within Gerontology department to } \\
\text { gain staff feedback and educate }\end{array}$ & $\begin{array}{l}\text { Set up a focus group with the nursing staff } \\
\text { within Gerontology to incite cultural } \\
\text { change of understanding and } \\
\text { communication, led by senior Matrons } \\
\text { DNACPR decisions and discussions will } \\
\text { now be reviewed on all new admissions to } \\
\text { Gerontology }\end{array}$ \\
\hline May 2018 & Presentation of findings at regional patient safety conference & $\begin{array}{l}\text { Promoted awareness and discussion of } \\
\text { electronic systems and DNACPR } \\
\text { decisions and how this relates to patient } \\
\text { safety }\end{array}$ \\
\hline June 2018 & $\begin{array}{l}\text { Amendment of the electronic process so it is now compulsory } \\
\text { to enter the name of a Nurse informed when submitting a } \\
\text { DNACPR order }\end{array}$ & $\begin{array}{l}\text { Unable to complete an electronic } \\
\text { DNACPR form without the mandatory } \\
\text { entry of a named Nurse informed of this } \\
\text { decision }\end{array}$ \\
\hline \multicolumn{3}{|c|}{ June 2018: Cycle 2 Data Collection } \\
\hline $\begin{array}{l}\text { September } \\
2018\end{array}$ & $\begin{array}{l}\text { Poster Presentation at the Society for Acute Medicine } \\
\text { National Conference }\end{array}$ & $\begin{array}{l}\text { Promoted awareness of completed audit } \\
\text { cycle and outcomes for other Trusts }\end{array}$ \\
\hline $\begin{array}{l}\text { November } \\
2018\end{array}$ & $\begin{array}{l}\text { Poster Presentation at the British Geriatrics Society Autumn } \\
\text { Meeting }\end{array}$ & $\begin{array}{l}\text { Promoted awareness of completed audit } \\
\text { cycle and outcomes for other Trusts }\end{array}$ \\
\hline $\begin{array}{l}\text { October } \\
2018\end{array}$ & $\begin{array}{l}\text { Meeting with local CCG to discuss project findings and how it } \\
\text { can be applied to other sites within Trust and to Primary Care }\end{array}$ & $\begin{array}{l}\text { Discussion regarding the design of a } \\
\text { DNACPR document / system which can } \\
\text { be transferred into Primary Care on } \\
\text { discharge }\end{array}$ \\
\hline $\begin{array}{l}\text { November } \\
2018\end{array}$ & $\begin{array}{l}3^{\text {rd }} \text { Data Collection at the Trusts other site for comparison of } \\
\text { performance within Trust }\end{array}$ & $\begin{array}{l}\text { Continuation of improvement across Trust } \\
\text { - ongoing }\end{array}$ \\
\hline
\end{tabular}

Abstract 43 Figure 1 Timeline and summary of interventions 


\begin{tabular}{|c|c|c|c|c|c|c|c|c|c|}
\hline $\bar{C} \overline{y c} \bar{e} \overline{1}$ & $\begin{array}{c}\bar{D} \bar{N} \overline{A C} \bar{P} \bar{R} \\
(n=133)\end{array}$ & $\begin{array}{cc} & \text { Resus } \\
\text { status \& } \\
\text { Treatment } \\
\text { Escalation } \\
\text { Plan in } \\
\text { toolbar } \\
: 133 \\
1 \\
100 \%)\end{array}$ & $\begin{array}{c}\text { Valid } \\
\text { e- } \\
\text { form } \\
\text { in } \\
\text { place } \\
y_{113} \\
(85 \%)\end{array}$ & $\begin{array}{c}\text { Made by } \\
\text { I a senior } \\
\text { doctor } \\
\text { (SpR or } \\
\text { I above) }\end{array}$ & $\begin{array}{l}1 \\
1 \\
1 \\
1 \\
1 \\
1 \\
1\end{array}$ & $\begin{array}{l}\text { Documented } \\
\text { discussion } \\
\text { with patient/ } \\
\text { relatives }\end{array}$ & $\begin{array}{l}\text { Docume } \\
\text {-nted } \\
\text { commun } \\
\text { ication } \\
\text { to MDT } \\
: 17 \\
(13 \%)\end{array}$ & $\begin{array}{c}\text { Decision } \\
\text { made } \\
\text { within } 24 \\
\text { hours of } \\
\text { admissio } \\
--\frac{n}{82}-- \\
(62 \%)\end{array}$ & $\begin{array}{l}\text { DNACPR } \\
\text { communi- } \\
\text { cated to } \\
\text { GP on } \\
\text { discharge } \\
-27 \\
(79 \%)\end{array}$ \\
\hline C̄ycle $\overline{2}$ & $\begin{array}{c}\bar{D} \bar{N} \overline{A C} \bar{P} \bar{R} \\
(n=126)\end{array}$ & $\begin{array}{cc}d & -\overline{126}- \\
1 & (100 \%)\end{array}$ & $\begin{array}{c}\alpha-\overline{126} \\
\mid(100 \% \\
\mid(1)\end{array}$ & $\left\{\begin{array}{c}11 \overline{7}- \\
1 \\
1\end{array}\right.$ & $\begin{array}{l}1 \\
1\end{array}$ & $\begin{array}{c}-\overline{89} \\
(71 \%)\end{array}$ & $\begin{array}{cc}-1 & -\frac{72}{1}-- \\
1 & (57 \%)\end{array}$ & $\begin{array}{c}-\overline{91}-- \\
(72 \%)\end{array}$ & $\begin{array}{l}-\overline{71}-- \\
(90 \%)\end{array}$ \\
\hline
\end{tabular}

Abstract 43 Figure 2 Data comparison pre and post interventions

Difficulty and distress when negotiating this transition can also be a barrier for patients and their families in engaging with the process of advanced or anticipatory care planning (Lund, Richardson \& May, 2015). Acceptance and Commitment Therapy (ACT; Hayes, Strosahl \& Wilson, 2011) is a promising but under-researched psychological intervention for supporting terminally-ill cancer patients (Arch \& Mitchell, 2015). We developed and are pilot-testing a brief ACTbased intervention to improve quality of life and psychological acceptance for this group. A multiple baseline, singlecase, non-controlled design is used. Ten participants have been recruited. Each receives five sessions with an ACTtrained facilitator, in the hospice setting. Quality of life, distress, and ACT-process changes are self-reported, weekly. Psychological flexibility and overall health are measured daily. The attrition rate is $60 \%$. One participant demonstrated measurement floor and ceiling effects, but small increases in psychological acceptance. Two participants demonstrated small changes in quality of life and psychological flexibility, with some level of distress reduction. Finally, one participant shows tentative improvements in psychological flexibility, despite overall health remaining low. Participant interviews and three staff focus groups provided feedback on acceptability and feasibility. This study will complete in August 2019. Findings to date suggest that ACT may be beneficial for patients transitioning to palliative care, but high drop-out and measurement issues raise feasibility questions.

\section{IPU OR ITU? IT ALL STARTS WITH PCT (PALLIATIVE CARE TRAINING)}

${ }^{1}$ Nicola White, ${ }^{2}$ Ollie Minton, 'Linda Oostendorp, 'Patrick Stone. 'University College London, UK; ${ }^{2}$ Brighton and Sussex University Hospitals NHS Trust, UK

\subsection{6/spcare-2019-mariecuriepalliativecare.44}

Background Impending death is not well recognised.1 Due to improvements in technology and medicine, people are living longer with more complex health conditions 2 and because of this, the death of a patient is an experience that many people entering a healthcare profession will have little of. As death occurs in any setting, at any time, it is vital that all healthcare professionals regardless of the setting they go on to work in, have adequate Palliative Care Training (PCT).

Aim To understand what current training is available on the recognition of dying at undergraduate level.

Methods An information gathering exercise of the following UK undergraduate courses: medicine, nursing, social work, physiotherapy, occupational therapy. All courses received an email asking what training was provided in recognising and communication of dying and what time was dedicated to this. Results 73/198 courses responded (37\%). 18/20 medical courses provided training in recognising dying with a median of 2 hours dedicated, and 17/20 in the communication of dying with a median of 3 hours dedicated. $80 \%$ $(43 / 54)$ of nursing and allied health professional courses provided some form of training in end-of-life care. Many of these courses expressed frustration at the lack of resources, funding, and time to include more training. Those with more time dedicated to PCT often had a 'champion' to advocate for it.

Conclusion Training in end-of-life care was inconsistent and variable across courses and professions. Further work on how we can support the champions in progressing PCT input on the courses is needed.

\section{REQUESTED WITHDRAWAL OF PEG FEEDING IN A PATIENT WITH MOTOR NEURONE DISEASE AND THE ROLE OF THE HOSPICE INPATIENT UNIT}

Donna Wakefield, Sarah Rhiannon Hanson. Marie Curie Hospice Newcastle, UK

\subsection{6/spcare-2019-mariecuriepalliativecare. 45}

Motor Neurone Disease (MND) is an incurable, progressive condition with an average prognosis of 2-3 years from onset of symptoms (Worms, 2001; Oliver 2019). NICE guidance (2016) recommends that a health care professional with expertise in palliative care should be an integral part of the MDT in managing often rapidly progressive symptoms, psychological distress and complex future care planning. Nutrition and weight loss are predictors of survival (Leigh et al, 2003) and often relate to progressive dysphagia (Heffernan et al, 2004).

Gastrostomy can be used to administer nutrition with studies suggesting this can both prolong survival and improve quality of life (Mazzini et al, 1995; Ganzini, 2006). It is important that the option to have gastrostomy is discussed at an early stage taking the patient's personal preferences into account (MND association, 2019). Patients with MND often have other interventions to try and optimise QOL such as Non-Invasive Ventilation (NIV). Recent literature describes the withdrawal of NIV at the request of patients with MND (LeBon \& Fisher, 2011; Messer et al, 2019) and the APM (2016) has issued guidance which considers the legal and ethical implications of this. However, a 